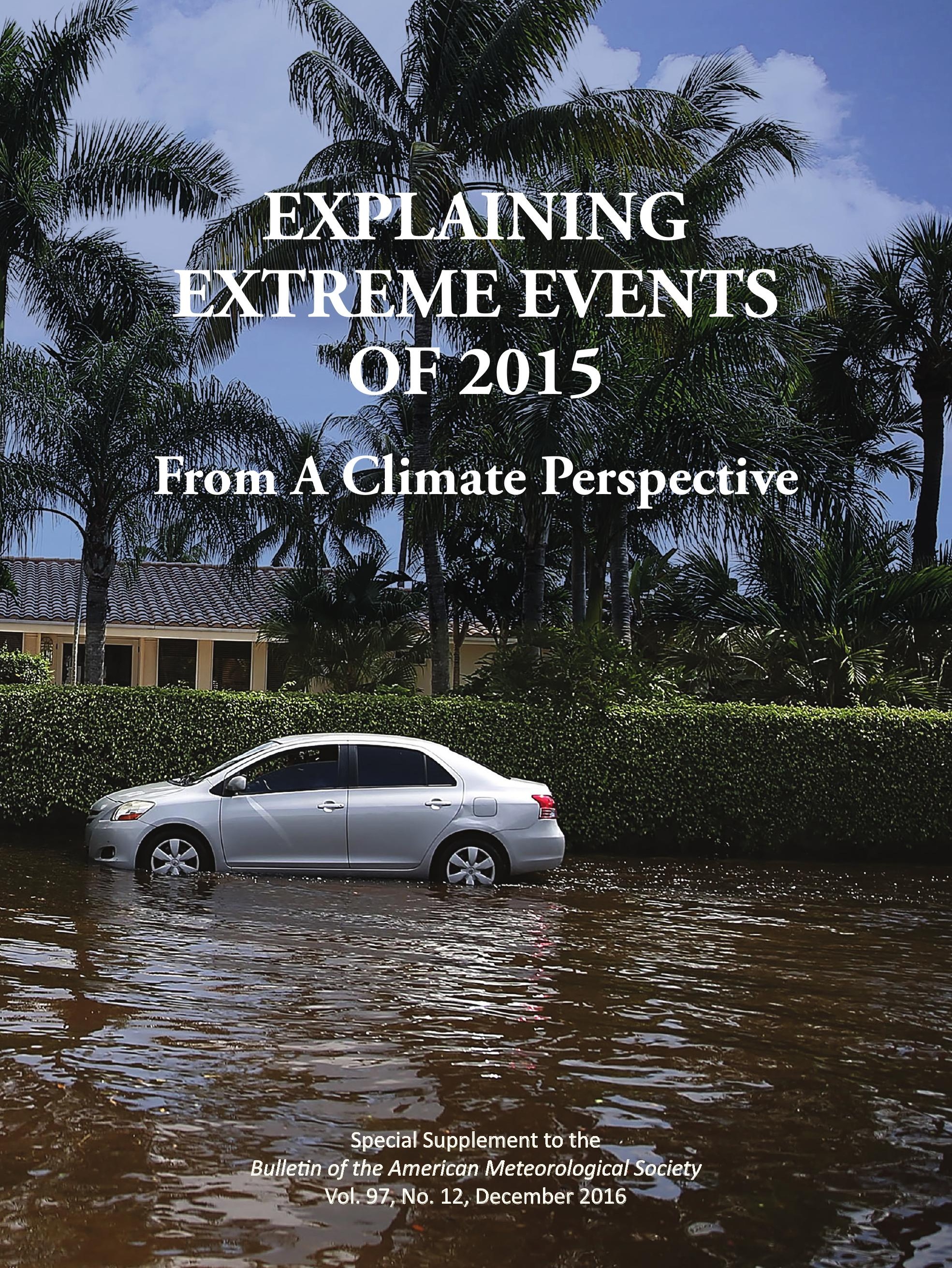




\section{EXPLAINING EXTREME \\ EVENTS OF 20I5 FROM A CLIMATE PERSPECTIVE}

\section{Editors}

Stephanie C. Herring, Andrew Hoell, Martin P. Hoerling, James P. Kossin, Carl J. Schreck III, and Peter A. Stott

Special Supplement to the

Bulletin of the American Meteorological Society

Vol. 97, No. I2, December 2016 


\section{CORRESPONDING EDITOR:}

Stephanie C. Herring, PhD

NOAA National Centers for Environmental Information

325 Broadway, E/CC23, Rm IB-I3I

Boulder, CO, 80305-3328

E-mail: stephanie.herring@noaa.gov

\section{Cover CRedit:}

CPhoto by Joe Raedle/Getty Images-A vehicle drives through flooded streets caused by a combination of the lunar orbit which caused seasonal high tides and what many believe is the rising sea levels due to climate change on September 30, 20I5, in Fort Lauderdale, Florida. South Florida is projected to continue to feel the effects of climate change, and many of the cities have begun programs such as installing pumps or building up sea walls to try and combat the rising oceans.

\section{HOW TO CITE THIS DOCUMENT}

Citing the complete report:

Herring, S. C., A. Hoell, M. P. Hoerling, J. P. Kossin, C. J. Schreck III, and P.A. Stott, Eds., 20I6: Explaining Extreme Events of 20 I5 from a Climate Perspective. Bull.Amer. Meteor. Soc., 97 (I 2), SI-SI 45.

Citing a section (example):

Partain, J. L., and Coauthors, 2016: An assessment of the role of anthropogenic climate change in the Alaska fire season of 2015 [in "Explaining Extremes of 2015 from a Climate Perspective”]. Bull. Amer. Meteor. Soc., 97 (I2), SI4-SI8, doi:I0.II75/BAMS-D-16-0149.

\section{EDITORIAL AND PRODUCTION TEAM}

Riddle, Deborah B., Lead Graphics Production, NOAA/NESDIS National Centers for Environmental Information,

Asheville, NC

Veasey, Sara W., Visual Communications Team Lead, NOAA/ NESDIS National Centers for Environmental Information, Asheville, NC

Love-Brotak, S. Elizabeth, Graphics Support, NOAA/NESDIS National Centers for Environmental Information,

Asheville, NC

Fulford, Jennifer, Editorial Support, Telesolv Consulting LLC, NOAA/NESDIS National Centers for Environmental Information, Asheville, NC

Griffin, Jessicca, Graphics Support, Cooperative Institute for Climate and Satellites-NC, North Carolina State University, Asheville, NC
Maycock, Tom, Editorial Support, Cooperative Institute for Climate and Satellites-NC, North Carolina State University, Asheville, NC

Misch, Deborah J., Graphics Support, Telesolv Consulting LLC, NOAA/NESDIS National Centers for Environmental Information, Asheville, NC

Osborne, Susan, Editorial Support, Telesolv Consulting LLC, NOAA/NESDIS National Centers for Environmental Information, Asheville, NC

Sprain, Mara, Editorial Support, LAC Group, NOAA/NESDIS National Centers for Environmental Information, Asheville, NC

Young, Teresa, Graphics Support, STG, Inc., NOAA/NESDIS National Centers for Environmental Information, Asheville, NC 


\section{TABLE OF CONTENTS}

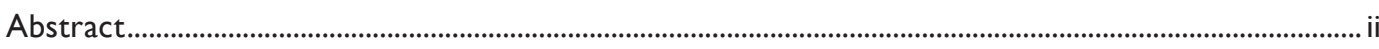

I. Introduction to Explaining Extreme Events of 2015 from a Climate Perspective.................................

2. Multimodel Assessment of Anthropogenic Influence on Record Global and Regional Warmth

During 2015 ........................................................................................................................................

3. What History Tells Us About 2015 U.S. Daily Rainfall Extremes ......................................................

4. An Assessment of the Role of Anthropogenic Climate Change in the Alaska Fire Season

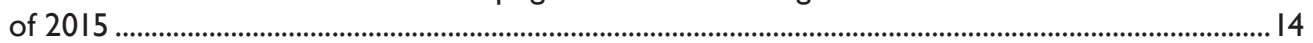

5. The 2014/15 Snowpack Drought in Washington State and its Climate Forcing ................................19

6. In Tide's Way: Southeast Florida's September 2015 Sunny-day Flood ................................................... 25

7. Extreme Eastern U.S. Winter of 2015 Not Symptomatic of Climate Change .....................................

8. The Role of Arctic Sea Ice and Sea Surface Temperatures on the Cold 2015 February

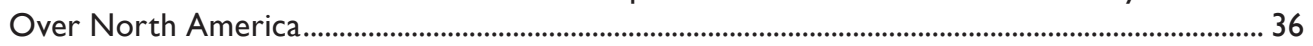

9. The 2015 Extreme Drought in Western Canada ................................................................................ 42

10. Human Contribution to the Record Sunshine of Winter 2014/15 in the United Kingdom .............47

II. The Role of Anthropogenic Warming in 2015 Central European Heat Waves ...................................5I

12. The 2015 European Heat Wave ....................................................................................................................

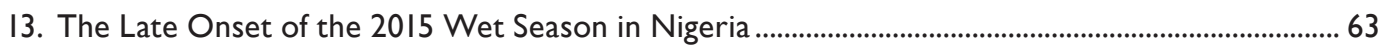

14. Human Influences on Heat-Related Health Indicators During the 2015 Egyptian Heat Wave .................................................................................................................................. 70

15. Assessing the Contributions of Local and East Pacific Warming to the 2015

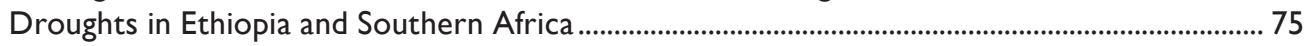

16. The Deadly Combination of Heat and Humidity in India and Pakistan in Summer 2015..................8I

17. The Heavy Precipitation Event of December 2015 in Chennai, India................................................... 87

18. Attribution of Extreme Rainfall in Southeast China During May 2015 ............................................. 92

19. Record-Breaking Heat in Northwest China in July 2015: Analysis of the Severity and Underlying Causes ........................................................................................................................... 97

20. Human Influence on the 2015 Extreme High Temperature Events in Western China................... 102

21. A Persistent Japanese Heat Wave in Early August 2015: Roles of Natural Variability and

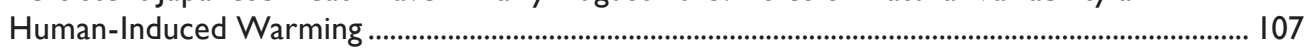

22. Climate Change and El Niño Increase Likelihood of Indonesian Heat and Drought........................ 113

23. Southern Australia's Warmest October on Record: The Role of ENSO and Climate Change....................................................................................................................................... 118

24. What Caused the Record-Breaking Heat Across Australia in October 2015? .............................. 122

25. The Roles of Climate Change and El Niño in the Record Low Rainfall in October 2015 in Tasmania, Australia.

26. Influences of Natural Variability and Anthropogenic Forcing on the Extreme 2015 Accumulated Cyclone Energy in the Western North Pacific

27. Record Low Northern Hemisphere Sea Ice Extent in March 2015 ............................................... 136

28. Summary and Broader Context.....................................................................................................141 
This fifth edition of explaining extreme events of the previous year (2015) from a climate perspective continues to provide evidence that climate change is altering some extreme event risk. Without exception, all the heat-related events studied in this year's report were found to have been made more intense or likely due to human-induced climate change, and this was discernible even for those events strongly influenced by the $2015 \mathrm{El}$ Niño. Furthermore, many papers in this year's report demonstrate that attribution science is capable of separating the effects of natural drivers including the strong 2015 El Niño from the influences of long-term human-induced climate change.

Other event types investigated include cold winters, tropical cyclone activity, extreme sunshine in the United Kingdom, tidal flooding, precipitation, drought, reduced snowpack in the U.S. mountain west, arctic sea ice extent, and wildfires in Alaska. Two studies investigated extreme cold waves and monthly-mean cold conditions over eastern North America during 2015, and find these not to have been symptomatic of human-induced climate change. Instead, they find the cold conditions were caused primarily by internally generated natural variability. One of these studies shows winters are becoming warmer, less variable, with no increase in daily temperature extremes over the eastern United States. Tropical cyclone activity was extreme in 2015 in the western North Pacific (WNP) as measured by accumulated cyclone energy (ACE). In this report, a study finds that human-caused climate change largely increased the odds of this extreme cyclone activity season. The 2015 Alaska fire season burned the second largest number of acres since records began in 1940. Investigators find that human-induced climate change has increased the likelihood of a fire season of this severity.

Confidence in results and ability to quickly do an attribution analysis depend on the "three pillars" of event attribution: the quality of the observational record, the ability of models to simulate the event, and our understanding of the physical processes that drive the event and how they are being impacted by climate change. A result that does not find a role for climate change may be because one or more of these three elements is insufficient to draw a clear conclusion. As these pillars are strengthened for different event types, confidence in the presence and absence of a climate change influence will increase.

This year researchers also link how changes in extreme event risk impact human health and discomfort during heat waves, specifically by looking at the role of climate change on the wet bulb globe temperature during a deadly heat wave in Egypt. This report reflects a growing interest within the attribution community to connect attribution science to societal impacts to inform risk management through "impact attribution." Many will watch with great interest as this area of research evolves in the coming years. 


\title{
17. THE HEAVY PRECIPITATION EVENT OF DECEMBER 2015 IN CHENNAI, INDIA
}

\author{
Geert Jan van Oldenborgh, Friederike E. L. Otto, Karsten Haustein, and Krishna AchutaRao
}

Extreme one-day rainfall caused widespread flooding in Chennai, India, in December 2015. No effect of global warming was detected, likely caused by aerosols counteracting greenhouse gases up to now.

Introduction. At the beginning of December 2015, the Indian state of Tamil Nadu experienced extensive flooding. November had been the second wettest month in Chennai $(1049 \mathrm{~mm})$ in more than 100 years, but the main floods were caused by one day of extreme precipitation on 1 December. The commercial center, Chennai (formerly known as Madras), reported 24-hr precipitation from $0830 \mathrm{LT}$ ranging from 77 to $494 \mathrm{~mm}$ at 18 stations, with a citywide-average of $286 \mathrm{~mm}$ (Fig. 17.1a). The city was declared a disaster area on 2 December after many areas, including the airport, were flooded. Although in the satellite-based CMORPH analysis the largest precipitation amounts were recorded south of Chennai (Fig. 17.1b), we concentrate our analysis on this city because the impact was largest here. Damages were estimated to be as high as $\$ 3$ billion (U.S. dollars; Wall Street Journal, 11 December 2015).

This part of India has its main rainy season during the northeast monsoon (Srinivasan and Ramamurthy 1973; Yadav 2013) in October-December. Sea surface temperature (SST) in the Bay of Bengal typically exceeds the threshold for deep convection throughout the year. Weak vertical shear during May and October-December (months prior to and immediately following the southwest monsoon) makes conditions ideal for tropical storms and cyclones that make landfall on the southeastern coast of India. The extreme rainfall events have sizes of $O(100) \mathrm{km}$.

SST in the northern and western Bay of Bengal has hardly increased over the last 35 years, in contrast to most of the rest of the world (Fig. 17.1c). This is likely because of increased air pollution in the region, the

AFFILIATIONS: VAN OLDENBORGH-Royal Dutch Meteorological Institute, De Bilt, Netherlands; Otto AND HaustelNEnvironmental Change Institute, University of Oxford, Oxford, United Kingdom; ACHUTARAO-Indian Institute of Technology Delhi, New Delhi, India.

DOI:10.II75/BAMS-D-16-0129.I "brown cloud," that blocks more sunlight counteracting the warming due to greenhouse gases, especially in premonsoon maximum temperatures (Padma Kumari et al. 2007; Wild 2012). The CMIP5 historical greenhouse gas (GHG) experiments without aerosols indeed indicate a larger trend in the Bay of Bengal (sea points in $\left.10^{\circ}-25^{\circ} \mathrm{N}, 80^{\circ}-90^{\circ} \mathrm{E}\right), 1.6^{\circ} \mathrm{C}(100 \mathrm{yr})^{-1}$ over October-December from 1970 to 2005, than the historical experiments, $1.3^{\circ} \mathrm{C}(100 \mathrm{yr})^{-1}$. This is still higher than the observed trend of $0.8^{\circ} \mathrm{C}(100 \mathrm{yr})^{-1}$. In line with this, SST anomalies were lower than elsewhere in the Indian Ocean in November-December 2015, although there was a warmer patch just off the coast of Chennai with $0.6^{\circ}-0.8^{\circ} \mathrm{C}$ anomalies (Fig. 17.1d). El Niño was also very strong these months.

Observational analysis. We analyze two datasets of daily station precipitation in the region. The public GHCN-D dataset (Menne et al. 2016) has 50 stations with at least 40 years of data in the area $10^{\circ}-15^{\circ} \mathrm{N}$, $79.5^{\circ}-81^{\circ} \mathrm{E}$ for a total of 3504 station-years. These coastal stations have similar climatologies of the wettest day of the year (RX1day). However, all but two of the series end in 1970. The India Meteorological Department (IMD) provided us with 19 nonpublic series with mean RX1day $>90 \mathrm{~mm}$ from the region for 1969-2013. Five of these did not have more than one or two years of valid data. One station had zeroes all through the wet season in a few years and was also discarded. Seven stations had monthly mean totals in 2001-04 that were about a factor of 10 smaller than satellite data; these years were deleted. A few very high precipitation amounts $(\geq 500 \mathrm{~mm})$ were on dry or moderately rainy days at other stations or in the satellite record and did not show up in flood records, so they were removed (displaced decimal points are common). After this quality-control procedure, 407 station years with at least $80 \%$ valid data in OctoberDecember remained. Both datasets were analyzed 
(a)
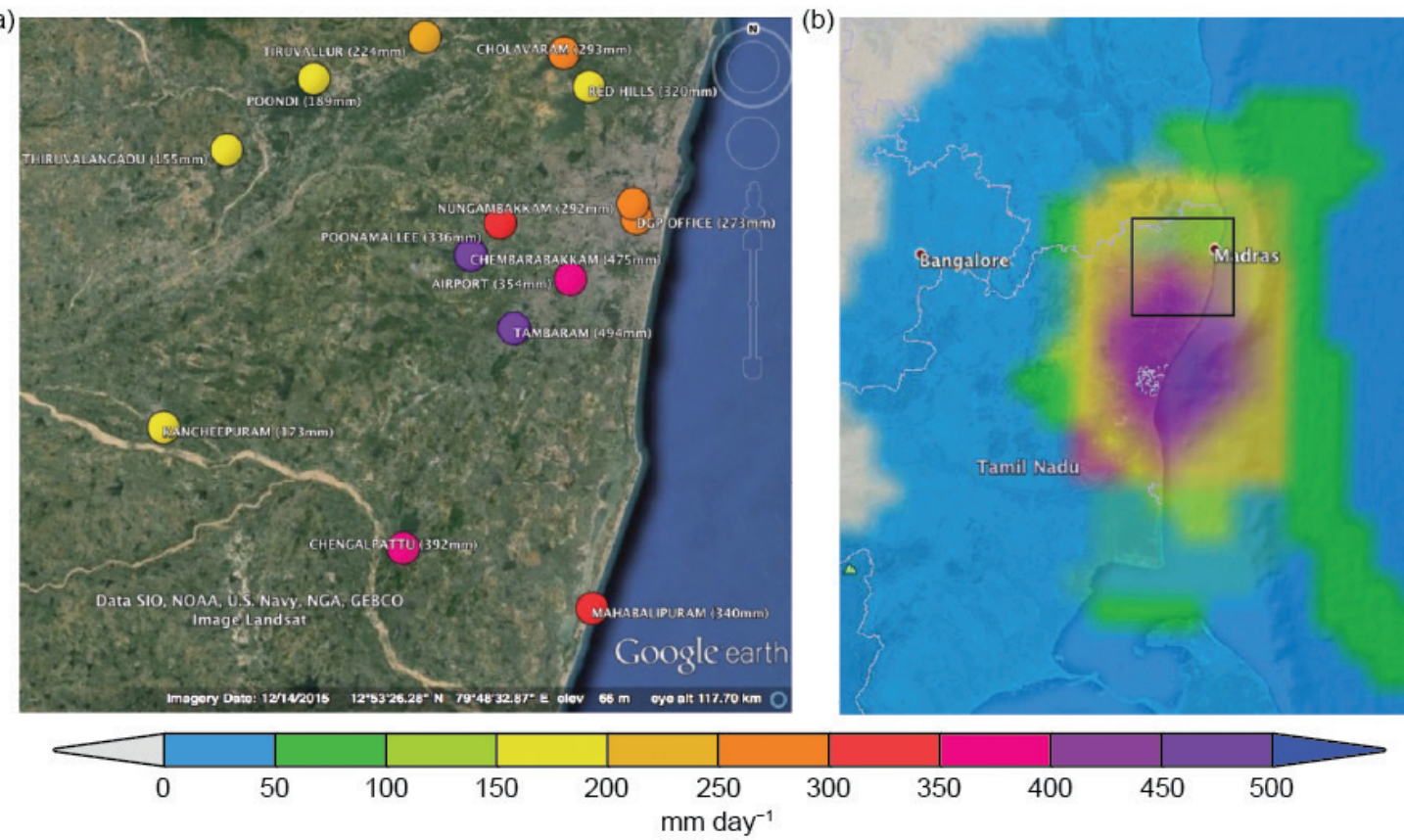

(c)

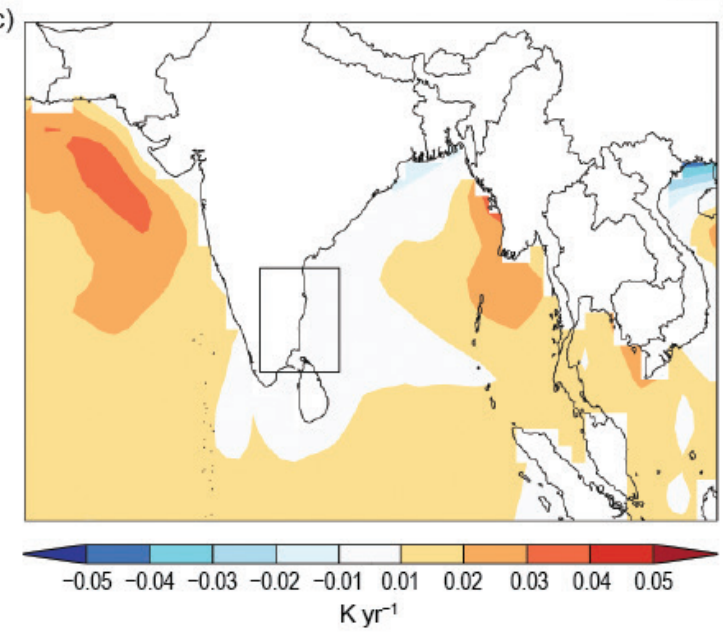

(b)
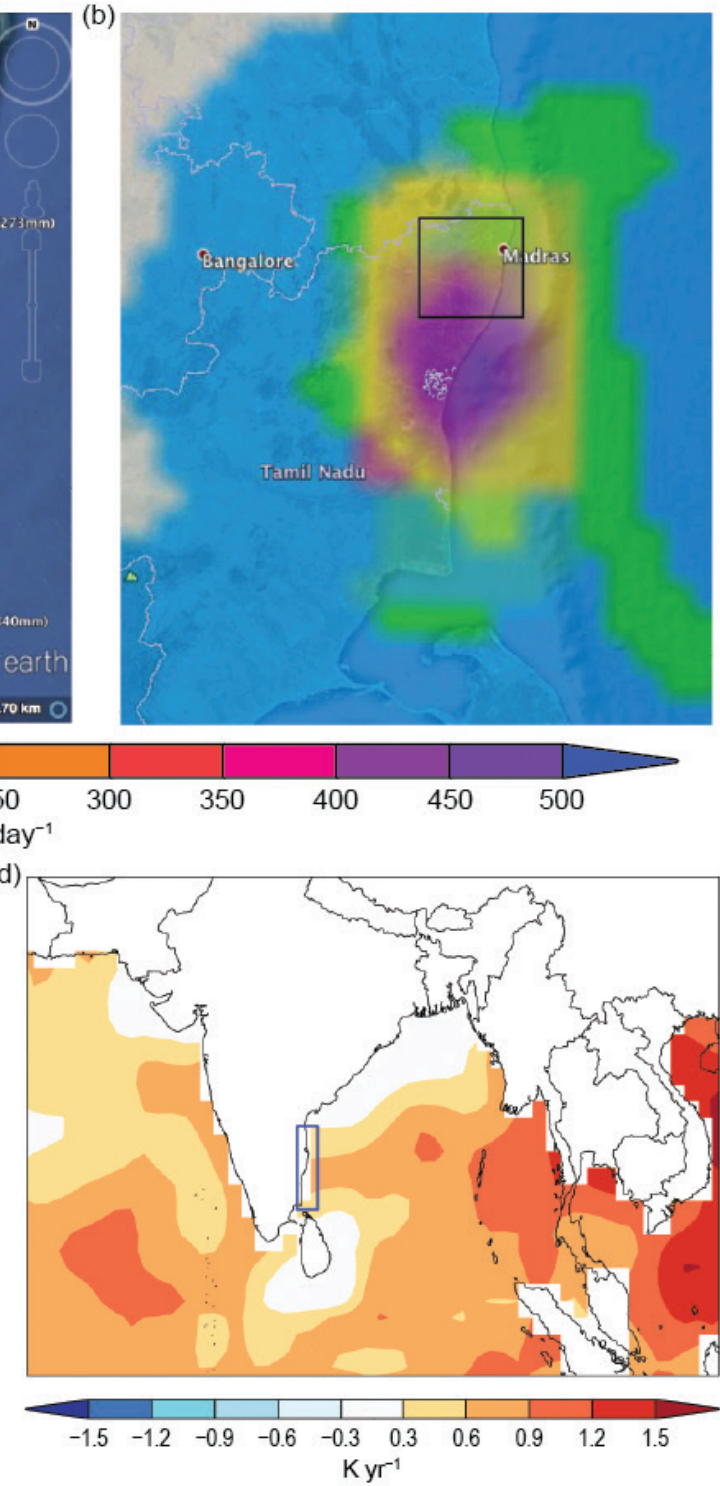

FIG. 17.I. (a) Rain gauge observations from 0830 LT of I Dec 2015 to 0830 LT of 2 Dec 2015 (mm day-1). The city of Chennai is visible in gray around the stations Nungambakkan and DGP Office in the city center. (b) Analyzed precipitation on 0000-2400 UTC I Dec 2015 (mm day-1; CMORPH, Joyce et al. 2004), the box indicates the region of panel (a). (c) Observed SST trend $\left({ }^{\circ} \mathrm{C}^{-1} r^{-1}\right)$ over the Bay of Bengal 198I-20I5 (SST OI v2, Smith et al. 2008). The box indicates the region of panel (b). (d) Observed anomalies $\left({ }^{\circ} \mathrm{C}\right)$ in Nov-Dec 2015. The blue box denotes the region investigated, the land area in $10^{\circ}-15^{\circ} \mathrm{N}, 79.5^{\circ}-81^{\circ} \mathrm{E}$.

separately with a fit to a generalized extreme value (GEV) distribution that scales with time (cf. Vautard et al. 2015), or the (ERSSTv4) Niño-3.4 index, assuming all stations have identical rainfall distributions. The uncertainties were estimated using a nonparametric bootstrap that takes spatial correlations into account with a 2D moving-block procedure analogous to the $1 \mathrm{D}$ one for temporal autocorrelations.

Both datasets show that the $494 \mathrm{~mm}$ observed in the Tambaram suburb is a rare event, with return times of 600-2500 years (95\% confidence interval; GHCN-D, assuming a stationary climate) and 300-4000 years (IMD; current climate, red lines in Fig. 17.2a) respectively. This means that the odds of receiving such extreme precipitation at a givenstation are less than $0.2 \%$ each year. The chance of such an amount occurring at any station in the region is higher. The rainfall in this area has around 5 degrees of freedom, so the return time for such a high amount in any rain gauge is five times lower. In fact, there is one 
(a) Oct-Dec Daily Stations Precipitation 1969-2013 (95\% Cl)
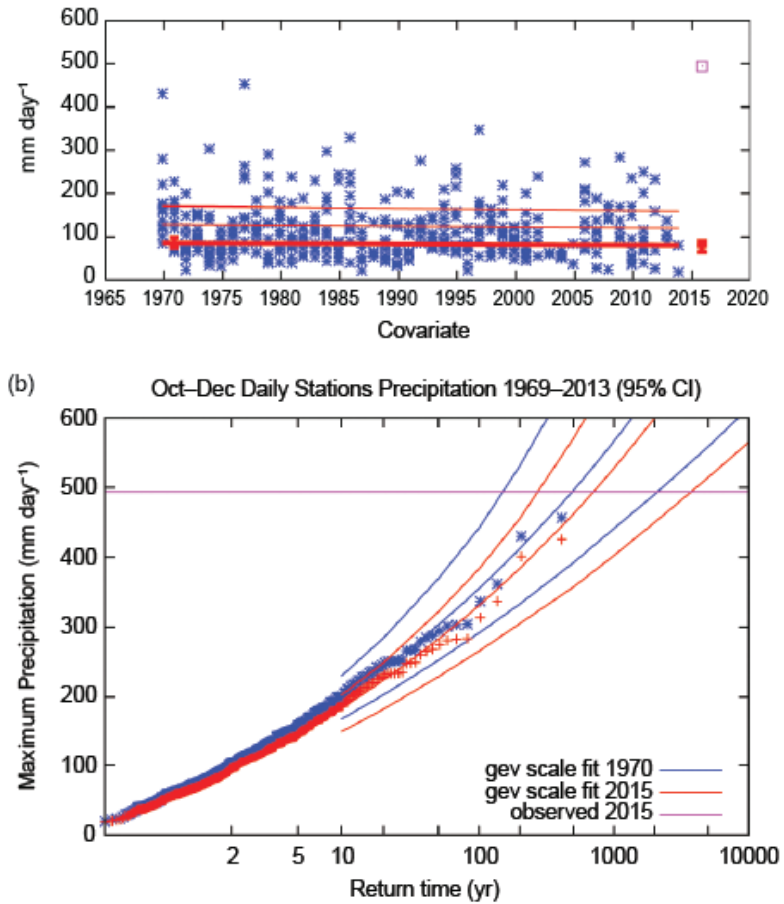

(c) Return periods of daily OND precipitation 2015

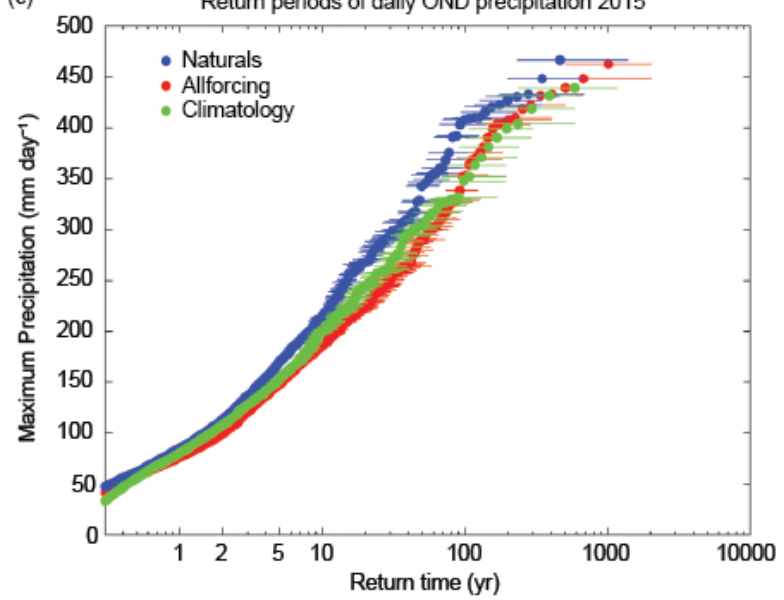

FIG. 17.2. (a) Maximum precipitation in Oct-Dec at 19 stations from 1969 to 2014 with a GEV fit in which the position parameter (thick red line) and scale parameter (difference between red lines) depend exponentially on time with their ratio constant. (b) Return time plot of these data with the GEV fit for 1970 (blue) and for 2015 (red) and 95\% uncertainties, the observations are also shown twice, shifted up (blue) and down (red) with the fitted trend. (c) Return times of maximum land grid box precipitation in the region $10^{\circ}-15^{\circ} \mathrm{N}, 77^{\circ}-82^{\circ} \mathrm{E}$ in the SST-forced regional model in the 2015 SST forced ensemble (red), the 2015 counterfactual world without anthropogenic emissions (blue) and the 1985-2014 climatology (green).

event in the GHCN-D dataset with higher precipitation: $500 \mathrm{~mm}$ at Vedaranayam on 18 November 1918.
The GHCN-D dataset (mainly up to 1970) shows no trend, whereas the IMD dataset shows a nonsignificant negative trend starting in 1969, see Figs. 17.2a,b. We conclude that there is no observational evidence for a positive trend. The $95 \%$ range is a factor $0.14-2.2$ increase in probability since 1970. A similar analysis using the Niño-3.4 index as covariate rather than time shows that there is a slight increase during El Niño, which is not significant at $p<0.1$ (one-sided). Total November-December precipitation is very weakly correlated with the Niño-3.4 index $(r$ $=0.18$, correlations reach $r>0.4$ further south along the coast). There is a stronger connection between mean precipitation and SST in the Bay of Bengal $\left(10^{\circ}-25^{\circ} \mathrm{N}, 80^{\circ}-95^{\circ} \mathrm{E}, r=0.30\right)$, which supports our hypothesis that the lack of trend in this area over the last 40 years is responsible for the lack of trend in extreme precipitation.

Global coupled climate models. We analyzed the rainfall extremes in a relatively high-resolution ensemble of model runs, 16 historical/RCP 8.5 experiments using the EC-Earth 2.3 model (Hazeleger et al. 2010) at T159, about $150-\mathrm{km}$ resolution. This model shows a strong positive trend in SST over the Bay of Bengal of about $0.2^{\circ} \mathrm{C}\left(10 \mathrm{yr}^{-1}\right)$ over $1975-2015$, which contradicts the observed trend. We therefore do not consider its modeled increase in the probability of high RX1day by a factor $1.6-6(95 \% \mathrm{CI})$.

The CMIP5 ensemble contains many models with a hard upper boundary of rainfall in the grid box corresponding to Chennai, in contrast to the observed probability distribution function (PDF; Fig. 17.2b), hence we could not use it either.

Regional climate model. We furthermore analyze the rainfall extremes in the regional atmosphere-only general circulation model HadRM3P, used in the weather@home distributed computing framework (Massey et al. 2015). The regional model over the CORDEX South Asian region (Giorgi et al. 2009) was employed at a $0.44^{\circ} \times 0.44^{\circ}$ resolution with a 5 -min time step is driven by the Hadley Centre model HadAM3P at $1.875^{\circ} \times 1.25^{\circ} \times 15$-min resolution. The initial conditions of the global model are perturbed at the first of December 2014 of every 13-month simulation to derive a set of very large ensembles of possible weather in the region of interest. Three different ensembles are simulated:

1) Simulations of the 13 months from December 2014 to December 2015 driven by observed (2015) 
SSTs and greenhouse gas concentrations $(n=2900)$,

2) Simulations of the same time frame in a counterfactual simulation $(n=6960)$ under preindustrial greenhouse gas and aerosol forcing and natural SSTs constructed by subtracting 11 different estimates of the human-induced warming pattern from the 2015 observed SSTs (Schaller et al. 2016), and

3) Climatological simulations of the years 1985 2014 with observed forcings to evaluate the reliability of the model as well as estimating the influence of the 2015 SSTs on the likelihood of the rainfall extremes.

Quantile-quantile assessments of the modeled precipitation reveal a small overestimation of the absolute values of precipitation but good representation of the overall distribution. Pressure over the region of interest is consistently underestimated. Because the biases in the model seem to be mainly an offset and we are comparing the model with itself in terms of magnitudes, we refrain from applying a bias correction. The SST difference between actual and preindustrial situations in the Bay of Bengal is about $0.5^{\circ} \mathrm{C}$ (Schaller et al. 2016, their Supplemental Fig. S17.3), in line with the observed trend.

To derive results comparable to the statistical analysis of the 19 stations described previously, we analyze daily maximum grid box precipitation in the October to November period over the region $10^{\circ}-15^{\circ} \mathrm{N}, 77^{\circ}-82^{\circ} \mathrm{E}$.

Comparing the two ensemble simulations for 2015 (Fig. 17.2c), we find again a nonsignificant negative change in the likelihood of extreme precipitation events with a return time above 100 years due to anthropogenic emissions. Comparing the simulations of 2015 with an ensemble of simulations of daily extreme rainfall from 1985 to 2014 reveals a small positive influence of the observed SST patterns on the likelihood of extreme rainfall. The analysis does not allow us to estimate the influence of the observed El Niño, only the global SST patterns. Qualitatively, the results are robust under different possible ways of characterizing the event spatially and temporally, by excluding the westernmost parts of the region or analyzing monthly data.

Discussion and conclusions. The observational analysis found no signal for a positive trend in extreme oneday precipitation at the southeastern coast of India over 1900-70, nor over 1970-2014. Coupled models show more extreme one-day precipitation events from 1970-2015, but a large ensemble of SST-forced models again shows no increase in the probability of extreme one-day precipitation due to anthropogenic emissions. A plausible factor is the lack of increase in SST in the western Bay of Bengal over the last 40 years, which is not reproduced correctly by the coupled models but is more realistic in the SST-forced model. This precludes an attribution of the floods to anthropogenic factors, probably to a large extent due to the two main pollutants, greenhouse gases and aerosols, having opposing effects. Over land this opposition is discussed by Padma Kumari et al. (2007) and Wild (2012).

There is a small but clear increase in probability of extremes in the SST-forced regional model, associated with El Niño and other SST anomalies. In the observations, the ENSO signal is also present but not statistically significant.

ACKNOWLEDGEMENTS. The station rainfall data (since 1969) provided by IMD is acknowledged. We would like to thank all of the volunteers who have donated their computing time to weather@home, and our colleagues at the Oxford eResearch Centre and the Met Office Hadley Centre PRECIS team for their technical expertise and scientific support. GJvO was supported by the FP7 EUCLEIA project under Grant \#607085.

\section{REFERENCES}

Giorgi, F., C. Jones, and G. R. Asgar, 2009: Addressing climate information needs at the regional level: The CORDEX framework. WMO Bulletin, 58, 175183. [Available online at http://public.wmo.int/en /bulletin/addressing-climate-information-needs -regional-level-cordex-framework.]

Hazeleger, W., and Coauthors, 2010: EC-Earth: A seamless Earth-system prediction approach in action Bull. Amer. Meteor. Soc., 91, 1357-1363, doi:10.1175/2010BAMS2877.1.

Joyce, R. E., J. E. Janowiak, P. E. Arkin, and P. Xie, 2004: CMORPH: A method that produces global precipitation estimates from passive microwave and infrared data at high spatial and temporal resolution. J. Hydrometeorol., 5, 487-503, doi:10.1175/1525 -7541(2004)005<0487:CAMTPG>2.0.CO;2.

Massey, N., and Coauthors, 2015: weather@home development and validation of a very large ensemble modelling system for probabilistic event attribution. Quart. J. Roy. Meteor. Soc., 141, 1528-1545, doi:10.1002/qj.2455. 
Menne, M., and Coauthors, 2016: Global Historical Climatology Network - Daily (GHCN-Daily), Version 3.22, doi:10.7289/V5D21VHZ.

Padma Kumari, B., A. L. Londhe, S. Daniel, and D. B. Jadhav, 2007: Observational evidence of solar dimming: Offsetting surface warming over India. Geophys. Res. Lett., 34, L21810, doi:10.1029/2007GL031133.

Schaller, N., and Coauthors, 2016: The human influence on climate in the 2014 southern England winter floods and their impacts. Nat. Climate Change, 6, 627-634, doi:10.1038/nclimate2927.

Smith, T. M., R. W. Reynolds, T. C. Peterson, and J. Lawrimore, 2008: Improvements to NOAA's historical merged land-ocean surface temperature analysis (1880-2006). J. Climate, 21, 2283-2296, doi:10.1175/2007JCLI2100.1.

Srinivasan, V., and K. Ramamurthy, 1973: Forecasting Manual Part IV: Comprehensive articles on selected topics. 18.4 Northeast monsoon. FMU Report No IV-18.4, India Meteorological Department, 130 pp. [Available online at www.imdpune.gov.in/weather _forecasting/Forecasting_Mannuals/IMD_IV18.4.pdf.]

Vautard, R., and Coauthors, 2015: Extreme fall 2014 precipitations in the Cévennes mountain range [in "Explaining Extremes of 2014 from a Climate Perspective”]. Bull. Amer. Meteor. Soc., 96 (12), S56S60, doi:10.1175/BAMS-D-15-00088.1.

Wild, M., 2012: Enlightening global dimming and brightening. Bull. Amer. Meteor. Soc., 93, 27-37, doi:10.1175/BAMS-D-11-00074.1.

Yadav, R. K., 2013: Emerging role of Indian ocean on Indian northeast monsoon. Climate Dyn., 41, 105116, doi:10.1007/s00382-012-1637-0. 


\section{Table 28.I. Summary of Results}

\section{ANTHROPOGENIC INFLUENCE ON EVENT}

\begin{tabular}{|c|c|c|c|}
\hline & INCREASE & DECREASE & NOT FOUND OR UNCERTAIN \\
\hline Heat & $\begin{array}{l}\text { Global Temperature (Ch. 2) } \\
\text { South India \& Sri Lanka (Ch. 2) } \\
\text { Central Europe (Ch. II) } \\
\text { Europe (Ch. I2) } \\
\text { Ethiopia and Southern Africa (Ch. I5) } \\
\text { N.W. China (Ch. I9) } \\
\text { W. China (Ch. 20) } \\
\text { Japan (Ch. 2I) } \\
\text { Indonesia (Ch. 22) } \\
\text { S. Australia (Ch. 23) } \\
\text { Australia (Ch. 24) }\end{array}$ & & Central Equitorial Pacific (Ch. 2) \\
\hline Cold & & Northeastern U.S. (Ch. 7) & $\begin{array}{l}\text { Mid-South Atlantic U.S. (Ch. 7) } \\
\text { N. America (Ch. 8) }\end{array}$ \\
\hline $\begin{array}{l}\text { Heat \& } \\
\text { Humidity }\end{array}$ & $\begin{array}{l}\text { Egypt (Ch. I4) } \\
\text { India \& Pakistan (Ch. 16) }\end{array}$ & & \\
\hline Dryness & $\begin{array}{l}\text { Indonesia (Ch. 22) } \\
\text { Tasmania (Ch. 25) }\end{array}$ & & \\
\hline $\begin{array}{l}\text { Heavy } \\
\text { Precipitation }\end{array}$ & China (Ch. 18) & & $\begin{array}{l}\text { Nigeria (Ch. I3) } \\
\text { India (Ch. I7) }\end{array}$ \\
\hline Sunshine & United Kingdom (Ch. I0) & & \\
\hline Drought & $\begin{array}{l}\text { Canada (Ch. 9) } \\
\text { Ethiopia and Southern Africa (Ch. I5) }\end{array}$ & & \\
\hline $\begin{array}{l}\text { Tropical } \\
\text { Cyclones }\end{array}$ & Western North Pacific (Ch. 26) & & \\
\hline Wildfires & Alaska (Ch. 4) & & \\
\hline $\begin{array}{l}\text { Sea Ice } \\
\text { Extent }\end{array}$ & & Arctic (Ch. 27) & \\
\hline $\begin{array}{l}\text { HIGH TIDE } \\
\text { FLOODS }\end{array}$ & SOUtheastern U.S. (CH. 6) & & \\
\hline $\begin{array}{l}\text { SNOWPACK } \\
\text { DROUGHT }\end{array}$ & WASHINGTON U.S. (CH. 5) & & \\
\hline TOTAL & 23 & 2 & 5 \\
\hline
\end{tabular}




\section{METHOD USED}

Heat

Heat \& Humidity

Dryness

Heavy

Precipitation

Sunshine

Drought

Tropical

Cyclones

Wildfires

Sea Ice

Extent

High TIDE

FLOODS

SNOWPACK

DROUGHT

\section{Ch. 2: CMIP5 modeling}

Ch. II: Observations; weather@home modeling

Ch. 12: HadGEM3-A modeling

Ch. 15: CMIP5 modeling

Ch. 19: CMIP5 modeling with ROF; FAR

Ch. 20: CMIP5 modeling with ROF; FAR

Ch. 21: MIROC5-AGCM modeling

Ch. 22: Observations; CMIP5 modeling

Ch. 23: weather@home modeling; FAR

Ch. 24: BoM seasonal forecast attribution system and seasonal forecasts

Ch. 7: Observations; CMIP5 modeling

Ch. 8: AMIP (IFS model) modeling

Ch. 14: weather@home modeling

Ch. 16: Non-stationary EV theory; C20C+ Attribution Subproject

Ch. 22: Observations; CMIP5 modeling

Ch. 25: Observations; Modeling with CMIP5 and weather@home

Ch. 13: Observations; Modeling with CAM5.I and MIROC5

Ch. 17: Observations; Modeling with weather@home, EC-Earth and CMIP5

Ch. 18: HadGEM3-A-N216 modeling; FAR

Ch. I0: Hadley Centre event attribution system built on the high-resolution version of HadGEM3-A

Ch. 9: Observations; CMIP5 modeling; Trend and FAR analyses

Ch. 15: CMIP5 modeling, land surface model simulations, and statistical analyses

Ch. 26: GFDL FLOR modeling; FAR

12

Ch. 4: WRF-ARW optimized for Alaska with metric of fire risk (BUI) to calculate FAR

Ch. 27: OGCM modeling

CH. 6: Tide-gauge data; Time-dependent EV statistical model

Ch. 5: Observations; CeSMI modeling 